TERRI TORY OF AJASKA

$P E-060-04$ DEPARTMIHT OF MINES

$$
\text { PE 60-4 }
$$

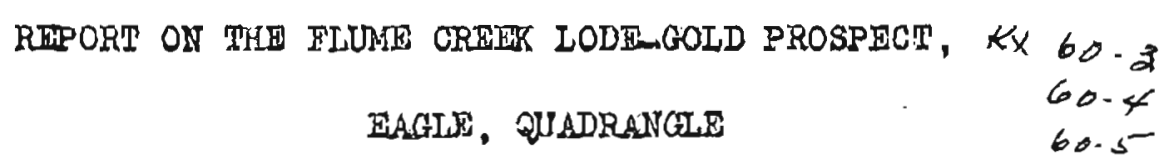

by

Robert F. Saunders Asgoclate Mining Fingineer

February 1956 


\section{INTRODUCTI ON}

A large, lok-grade, lodemgold prospect on Fiune Creek tritu utary to the Siventymile River, has been known to prospector in interior llakke for many yearg, but it has not been descrlbed in eny reports on the region. The prospect wa diacovered by the Eudson brothers in the early $1900^{\circ}$; after being abandoned by them, the claims reverted to the public domaln, and shortly after horld Har II the prospect was staked by Mr. Frod Jenkine of Nagle. During the past few years be hae been doing exploration and develops ment work on 1t. The elaing now belong to the Alaske Nickel Compeny, of which Mr. Jenkdne is a mojor otookholder. In 1955, fiold 1nvestigations for the Depertment of Minos necessitated a trip through the seventymile River councry, and providea an opportuni ty to obtaln information about the Flume Creek gold proppect for the Department of Mineg. Accordingly, an examination of the prospect wag made in July 1955 by Robert H. Saunders, Nsoolate Mining Ingineer. This report L written from notes taken during that examination.

\section{GENERAL INFORMATION}

The Fune Creek gold prospet is in the north-central part of the Eagle Oradrangle et $64^{\circ} 56^{\prime}$ if lat1tucle and $142^{\circ} 30^{\prime}$ H longlude. Throdghout a major part of 1 ts course, Fiume Craek flows through a narrow, ateep-walled cangon; about onewhalf mile fram its mouth the creek energes from the canyon and flows through a narrow, rounded valloy to the Seventymile River. The matn 
outcropa of the prospect are at the lower and of the canyon on both sides of the creek.

The Seventymile Rivor is not navigable for reany miles down Btroem from the mouth of Fiume Crook. Froight must be brought to the prospect either by tractor up the Sorentymile River on the $1 c 0$ in the winter or by air. Frefght hauled in by tractor would come through Fegle, and the distance by trall from Bagle to the prospeot would be about 60 mileg. There is a small alrstrip on the ridge on the east side of Alder Creek, and there is a foot trail aboot flve miles lone from the alratrip to Flume Croek. The first mining on Flume Creek was the mining of gold placor deposits. The area that wes minod is on the left 11 mit side ebout one-quarter mile above the mouth of the creok; it is about 200 feet long and 50 feet wide. The tellings and the outlibe of the old rolitugs are stlll discernible. To obtaln water for mining, the early miners built a flume 3000 feet long through the Fiume Exeek canyon; rotted parts of the flune are now scattered along the lower part of the canyon.

On srotic Greak, a tributary to wame Creek that heeds on Aretio Dome, there was a mall placer operation, which Mr. Jenteng says produoed only about $\$ 600$. Solde from that there has been no placer mining on Fiune Creele upstrean from the outcrops of the lode at the lower and of the canyon.

A few tributaries of the Seventymtio River downstream from Fume Creek havo produced placer gold: the post Important of these 
are Alder, Barney, and Crooked creaks. Barney Hangen of Eagle is mining on Crooked Creek, and his is the only active placer mine is the Seventymile River wotershed at the present time. Probably there has been some prospecting on:all the tributaries of the Seventymile Rtiver. After the eno of World Wer II, tho Uniteả States Smelting Refining and Mining Company did some prospect orilling in the main Seventymile River valley. Clnnabar has been reported on Cinyon Greek, e. tributary that flows into the Seventymlle River about 20 miles domotream from Flume Creok.

GEOLOGY AID MINERAL DEPOSITS

The geology of thl p part of Alaska has been degoribed in U. 5. Geologicel Surveg Bulletin 872, THE YUKOL TANANA RHGION, AIASKA, by J. B. Mertie, Jr. Fom the mouth of Munie Craek for several miles downstream the bedrock in the velley of the Seventymlie River ia pre-Cambrian B1rch Creek Schist. The main headwater tributarles of Flume Creak heed in bills of grent te and quartz diorite, a part of the Charley River betholith. Throughout most of 1 ts length, Flume Creek flows over a group of metamorphosed sediments of Devonlan age. Near the mouth of Flume Creek, there is a mell area in which the bedrook is a basic intrugive rock, al so of Devonfan age. The generel strike of contacts between the different rock unts 1 s about 700 i.

The lode 18 a shear zone in the Deronten metamorphic rocks, end, within the zone, pyrite, arsenopyrite, ond free gold are diseminated. There is a large outerop of the zone on each 
side of Flune Creek and on each side of Bonanza Creek, the next tributary to the Seventymile River dowatream from Flune Creek. All of the outcrops have weathered to a congplcuous reddiob color. The distance between: the outcrops on $F^{3}$ ume Crook and the outcrops on Bonanze Creek is about one mile. On the north alde of the Seventymile River about three miles upstream from the mouth of Flume Creek there is enother outerop of a simliar color, which may mark the northwestward extension of the minerelized zone. This outerop 1s congpicuous when the sunl1ght atrike it at the proper anglo, but otherwise it is difficult to $8 \theta$ from a distance. The atrike of the minerallzed zone from Bonenza Creok to Flume Creok is betweon $\mathbb{N} 30^{\circ} \mathrm{W}$ and $\mathrm{N} 60^{\circ} \mathrm{H}$, and the zone dips about $40^{\circ}$ southwest.

On the left limit gide of Fume Creak there 1 a a large telius slope consiating of rock that has broken from the outorop of the mineralized zone. Thts tolus pile may prove to be the firet part of the deporit to be mined.

Fred Jenkins has had essays ruy on many samples during the time that he has been woskding on Flume Creek. From samplea from the telue slope on the west alde of the creek, he estimates. that the talus pile containg 10,000 tons of ore that will arerage $\$ 9$ per ton. small amount of the talus has been pat through the mill but not enough to verify this estimate. From the outcrop of the minerelized zone on Bonanze Creek he has obtained gamples that ran as high as $\$ 54$ per ton. Several pans of waathered 
material were taken from the outcrop on Bonanze Creek during thit examination; an expreclable amount of gold was recovered in each pan, however, one sample of this material was asaged at the College Assay Office, and 1 t contained only a trace.

\section{WORKINGS AND EVUIPNENT}

On the east side of BI. ume Creek there is en eift that wes driven by the Budson brotbers in the early $3900^{\prime} \mathrm{s}$. From the portal the adt goes about 50 feet due eagt; there it tarns to the north and goes another 10 feat to the faco. Fiftoen feet In from the portal there is a turnoff about 16 feet long to the south. The adit gtarts near the honging wall of the mineralized zone and pertly orossouts the zone. At the exposures on Bonanza Creek there are some small surface trenches that have been dug by Fred J enkins.

On Fime Creok about 100 yards domstream fram the outcrops of the minerelized zone there is a cabin. Fred Jenting has repalred the cabin and 18 using it for living quarters; it is now in excellent condition.

On the ridge on the west side of Flame Creek, Fred Jenking has started building an airstrip. In July 1955 the moss had been removed from the new alrstrlp exposing fine-grefned, frozon silt. Water from the thawing ico in the silt made the airstrip much too wet for alrcraft landings, and al though he hoped to be able to draln the water off, there was some doubt that the airstrip ever would be serviceable. 
The ugual hand tools required for prospecting are on the property, and it addition there are a small baII-mill and a "Terratrec", a small gasollne-powered, crawler-typo trector. The tractor is equipoed with a front end laader. The ball-mill has been erected at the foot of the lerge talus slope on the best stie of Fune Creek. During the winter of $1954-55$ a Iarge boulder carne down the slope and broke the feeder on the mill; in July 1955 the mill had not been repeired. There is no clastifier to permtt the mill to run in closed circuit; a slaice box, or launder, is the only gold-saving device.

\section{PLARDTED OPRRATIONS}

Fred Jenkling plans to etert mining in the talus plle on the west side of Hume Creok. In doing go be will uge the "Terretrac" to dis the telus and dump it into the ball-mill feeder. Presumebly, before be minea much of the talus pile he will add equipment that Hil 1mprove the milling procedure. The mintug of the taluo wil give some indication of the grade of the mineraltzed zone, at least in the vicinity of Flume Creek. On Bonanze Creek there is much weathered material over the outer op thet perhepe could be placers mined profitably, howerer, the outcrop is 100 feet or roore above the creek and pursing would be necessary.

men if Thed Jenking is unsuccesgful in his mining, some tine in the future this deposft may support a large-scale mining operation. 


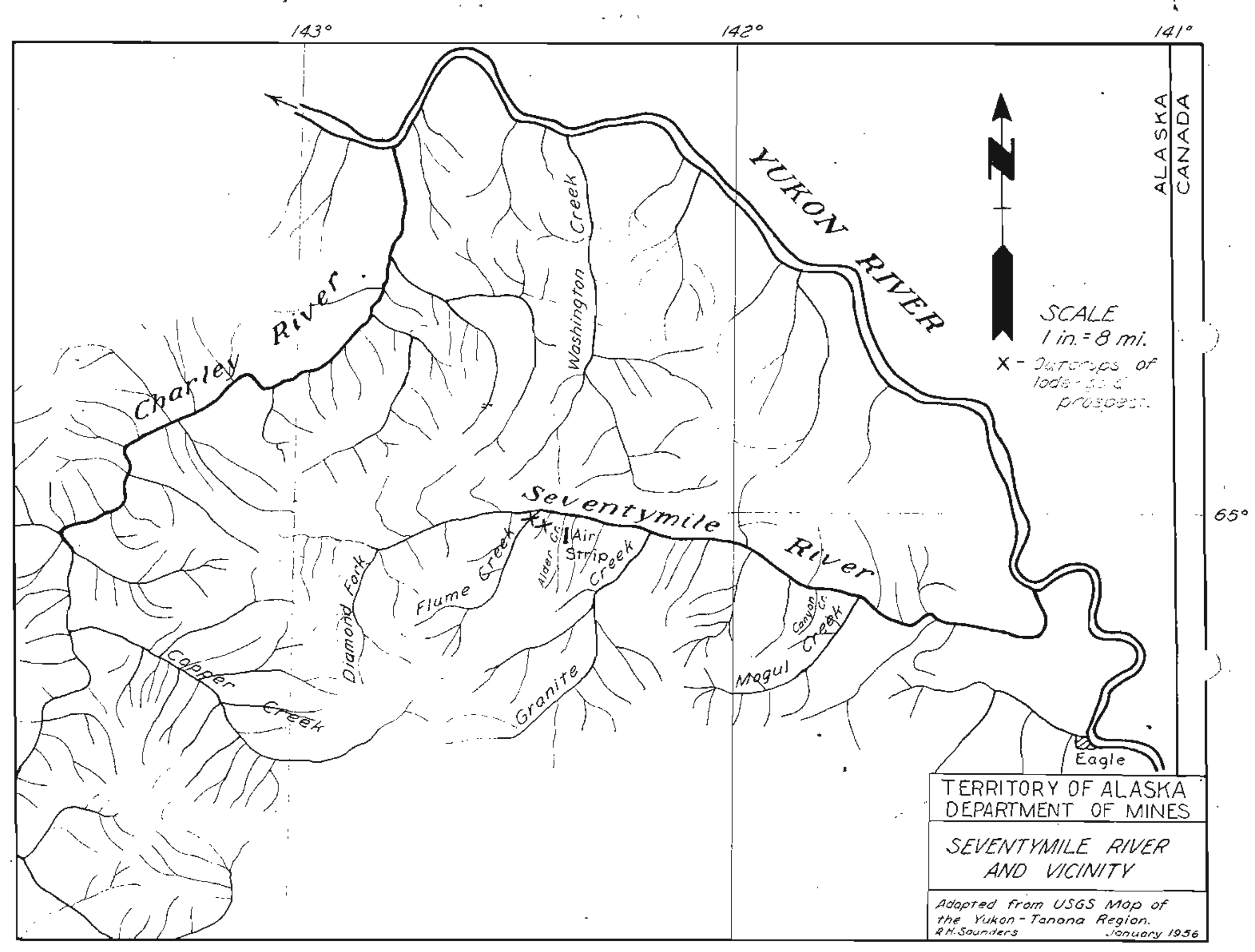




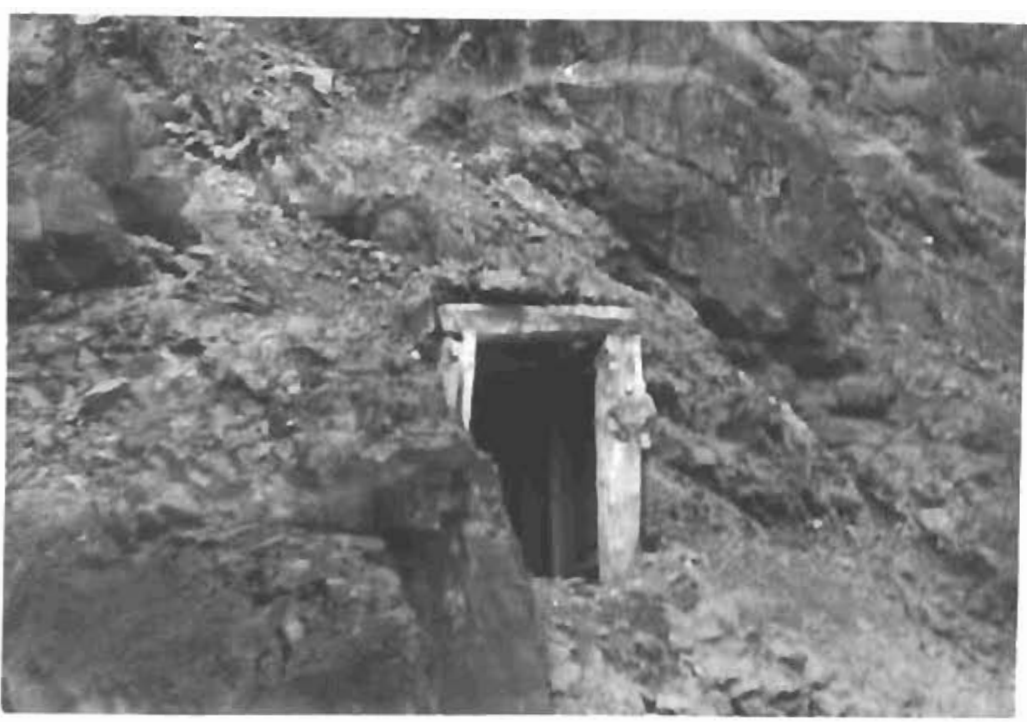

Portal on east side of Flume Creek.

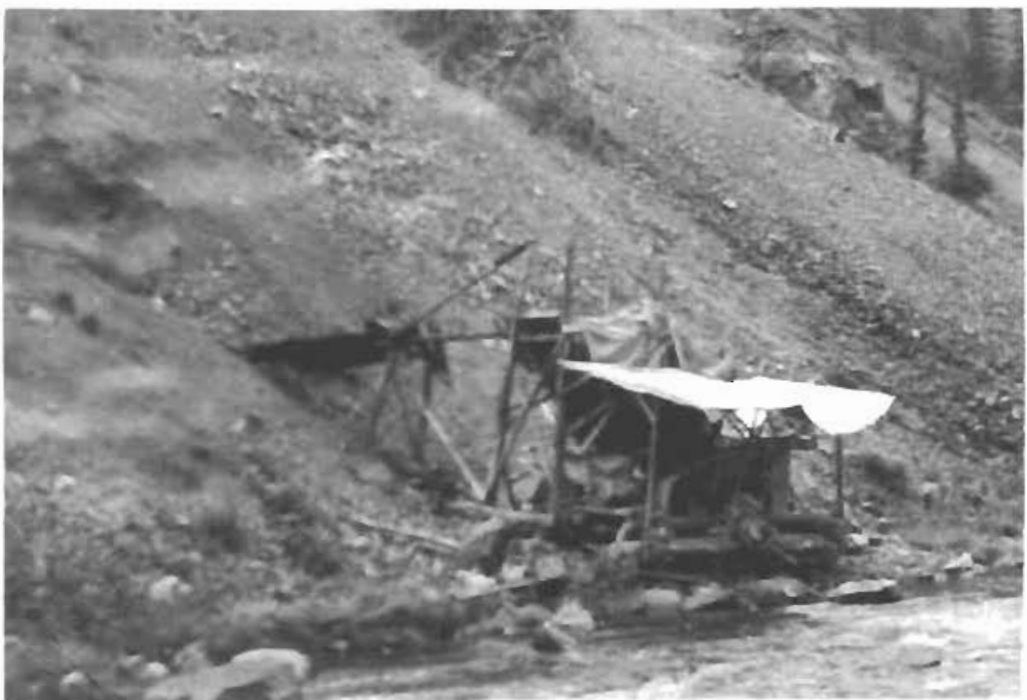

MII at toe of talus slope on west side of Flume Creek. 


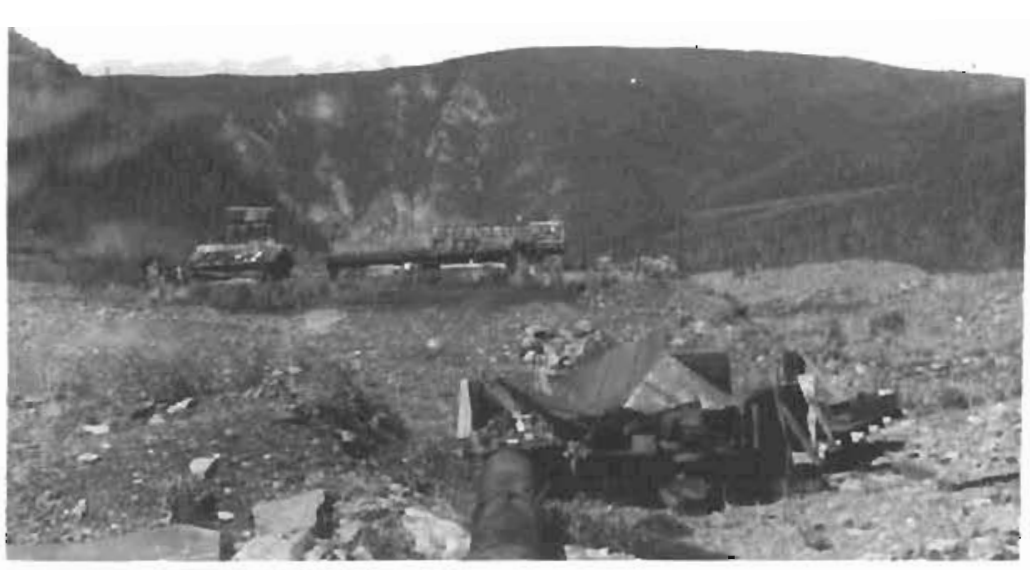

Abandoned workings and camp on Alder Creek. 